\section{Научные направления работы кафедры проектирования лесного оборудования Сибирского государственного технологического университета}

\author{
В. Ф. Полетайкин ${ }^{1}$ \\ Сибирский государственный технологический \\ университет
}

\begin{abstract}
АННОТАЦИЯ
В статье рассмотрены научные направления работ кафедры по повышению технического уровня лесных подъемно-транспортных машин.

Ключевые слова: лесопогрузчики, надежность, эргономика, динамические системы, моделирование, оптимизачия.
\end{abstract}

\section{SUMMARY}

The directions of work on increasing of the technological level of wood hoisting-and-transport machines are considered in this article.

Keywords: loggers, reliability, ergonomics, dynamic systems, modelling, optimization.

В лесной промышленности России при заготовке древесного сырья в виде хлыстов и деревьев с кроной используются системы лесотранспортных машин, в состав которых входят гусеничные лесопогрузчики перекидного типа. Установлен типоразмерный ряд по их главному параметру - грузоподъемности: 25 , 35, 63 кН, обеспечивающий погрузку древесины на лесосеках во всех природно-производственных условиях. На базе лесопогрузчиков перекидного типа была освоена технология лесозаготовок с отделением трелевки от погрузки, удостоенная Государственной премии СССР в области науки и техники. Эта технология и в настоящее время широко используется в лесной промышленности. Основным средством вывозки древесного сырья с лесосек продолжают оставаться автопоезда. Существенное изменение в развитии других видов лесотранспорта в ближайшие 15-20 лет маловероятно. Поэтому самоходные лесопогрузчики различных типов и в будущем будут широко применяться в лесной промышленности.

Одним из главных показателей технического уровня и качества лесопогрузчиков, как и других машин, является надежность, так как она определяет ритмичность лесосечных работ и последующих фаз производства.

\footnotetext{
1 Автор - заведующий кафедрой проектирования лесного оборудования, д.т.н., профессор

(C) В. Ф. Полетайкин, 2003
}

Условия эксплуатации лесных машин в Сибири и на Дальнем Востоке отличаются специфическими особенностями - крупномерные древостои, низкая несущая способность грунтов, низкие температуры и т. д. Поэтому проблема повышения надежности лесопогрузчиков с учетом региональных условий эксплуатации, обеспечения их конкурентоспособности на рынке лесных машин является актуальной. С учетом этого на кафедре проектирования лесного оборудования (ПЛО) СибГТУ проводятся работы по совершенствованию методов проектирования и расчетов рабочего оборудования лесопогрузчиков различных типов на основе анализа динамики внешних возмущений и элементов конструкции, применения методов оптимизации кинематических параметров на стадии проектирования. С этой целью были разработаны формализованные эквивалентные динамические системы и их математические модели, учитывающие тип ходовой системы базовой машины, упругие и демпфирующие характеристики подвески корпуса, металлоконструкции и гидропривода рабочего оборудования и груза. Источниками внешних возмущений служили детерминированные нагрузки и вероятностные характеристики случайных процессов взаимодействия корпуса и ходовой системы базовой машины с опорной поверхностью. Моделирование рабочих режимов позволяет определять влияние на уровень динамических нагрузок конструктивных и эксплуатационных факторов, получать значения коэффициентов динамичности, величину и характер действующих нагрузок на элементы системы. Проектирование новых лесопогрузчиков с учетом полученных данных обеспечивает повышение показателей надежности, а также служит основой для назначения безопасных эксплуатационных режимов [1].

Одним из направлений создания теоретических основ проектирования лесотранспортных машин является использование статистической динамики, применение вероятностно-статистических методов исследования. Для определения главных параметров случайных процессов внешних возмущений выполнены экспериментальные исследования, в результате которых получено необходимое количество реализаций процессов. Методами корреляционного и спектрального анализа определены их вероятностностатистические характеристики.

Наряду с надежностью важнейшими показателями технического уровня лесопогрузчиков являются эргономические показатели, в том числе эффективность системы виброизоляции сиденья оператора. При агрегатировании лесопромышленных тракторов с рабочим оборудованием лесопогрузчиков вибрационная характеристика изменяется, так как появляются дополнительные источники высокочастотных колебаний (гидропередача, предохранительная аппаратура и т. д.), изменяется масса машины. Кроме этого, на вибрационную характеристику оказывают влияние специфические режимы работы лесопогрузчика. В связи с этим проводятся исследования по разработке методики оценки на стадии проектирования эффек- 
тивности системы виброизоляции рабочего места оператора лесопромышленного трактора при использовании его в качестве базовой машины лесопогрузчика. С этой целью были исследованы случайные процессы вертикальных колебаний основания сиденья при работе лесопогрузчика и получены характеристики возбуждений колебаний - спектральные плотности ускорений основания. По известным динамическим характеристикам подвески сиденья и внешних возмущений можно на стадии проектирования прогнозировать эффективность системы виброизоляции лесопогрузчика при различных сочетаниях переменных факторов (тип подвески корпуса, масса оператора, тип подвески сиденья и т. д.) в различных октавных полосах частот и проводить работы по доведению параметров вибрации до уровней, установленных нормативно-технической документа-цией [1], [2].

Одним из основных направлений поисковых исследований кафедры является разработка и обоснование параметров кинематики и динамики рабочего оборудования лесопогрузчиков перекидного типа. Выпускаемые в настоящее время Красноярским заводом лесного машиностроения лесопогрузчики ЛТ65Б и ЛТ188 разработаны на основе авторского свидетельства 288663 (авторы В. Ф. Полетайкин, В. П. Глазырин). С целью обоснования параметров кинематической схемы были разработаны математические модели движения стрелы с грузом и алгоритм оптимизации рабочего оборудования по критерию $\min \{\max \}$ усилий на штоках гидроцилиндров привода, реализованный на ПЭВМ. Одновременно решались задачи по снижению пиковых нагрузок на элементы конструкции рабочего оборудования.

Наряду с работами по совершенствованию лесопогрузчиков перекидного типа выполняются поисковые исследовательские и опытно-конструкторские работы по созданию поворотных лесопогрузчиков с телескопическими и комбинированными манипуляторами. Поворотные лесопогрузчики с телескопическими стрелами обладают рядом преимуществ (компактность конструкции, высокая кинематическая точность механизмов, широкие технологические возможности и т.д.). Кинематика и компоновка рабочего оборудования позволяют выполнять операции подсортировки древесины перед ее отгрузкой, штабелевку сортиментов, многие вспомогательные работы. С целью обоснования кинематических и динамических характеристик рабочего оборудования проводятся исследования эксплуатационных режимов таких лесопогрузчиков. В сложившихся условиях выполнить натурные эксперименты практически не представляется возможным. Поэтому исследования выполняются на математических и физических моделях. На кафедре ПЛО с этой целью была разработана и изготовлена физическая модель поворотного лесопогрузчика с трехсекционной телескопической стрелой. Модель строилась по семнадцати критериям подобия относительно натуры, в качестве которой была использована конструкторская документация лесопогрузчика, раз- работанного также на кафедре [3]. Физическая модель оснащена информационно-измерительной системой, скомпонованной на основе персонального компьютера, платы аналого-цифрового преобразования, 10-канального тензометрического усилителя. Система также включает в себя 18 различных датчиков и блок питания [4]. Данные измерений, проводимых в процессе экспериментов, записывались на жесткий диск ПЭВМ. Обработка результата выполнялась в пакете MathCAD.

На основе результатов теоретических и экспериментальных исследований разработана конструкция поворотного лесопогрузчика с грузовым моментом $160 \ldots 210$ кН*м, оснащенного трехсекционной телескопической стрелой на базе гусеничного лесопромышленного трактора. Однако в металле эти машины не изготавливались. Кроме рассмотренных направлений на кафедре проводятся работы, связанные с технологией и оборудованием природообустройства и защиты окружающей среды, механизацией лесохозяйственных работ, с исследованиями влияния техногенных воздействий, обусловленных строительством крупнейших гидроэнергетических комплексов (ГЭС, водохранилище, город) на состояние лесных экосистем. В этом направлении проводились работы по обоснованию технологии и систем машин для лесной рекультивации отвалов угольных разрезов Красноярского края, создания лесных культур на переувлажненных почвах и другие работы. Результаты научных исследований, как правило, используются в учебном процессе. Кафедра ПЛО является выпускающей по специальностям 170400 и 171100. При кафедре имеется аспирантура и докторантура по специальности 052101.

\section{СПИСОК ЛИТЕРАТУРЫ}

1. Полетайкин В. Ф. Моделирование рабочих режимов тракторных лесопогрузчиков: Монография. Красноярск, 1996. 248 с.

2. Полетайкин В. Ф., Авдеева Е. В. Оценка параметров виброизоляции системы «Оператор - сиденье» лесопогрузчика на стадии проектирования // Известия вузов. Лесной журнал. 1997. № 4. C. $42-45$.

3. Полетайкин В. Ф., Мосеев Е. Н., Сергин М. Е. Техника измерений нагруженности мобильных машин // Строительные и дорожные машины. 2001. № 1. С. 26-27.

4. Полетайкин В. Ф. К вопросу совершенствования лесопромышленного оборудования // Известия вузов. Лесной журнал. 1999. № 5. С. 117-118.

5. Мосеев Е. Н. Нагрузочные режимы в телескопической стреле поворотного лесопогрузчика: Автореф. дис. ... канд. техн. наук. Красноярск, $2001.22 \mathrm{c}$. 